\title{
PENTINGNYA MINAT BACA DALAM MENDORONG KEMAJUAN DUNIA PENDIDIKAN
}

\author{
Efri Yoni \\ Fakultas Keguruan dan Ilmu Pendidikan, \\ Universitas Muhammadiyah Sumatera Barat, \\ efriyoni14@yahoo.com
}

\begin{abstract}
ABSTRAK
Diantara berbagai masalah pendidikan di Indonesia adalah rendahnya minat baca. Kebiasaan dan budaya baca dapat mengembangkan ilmu pengetahuan dan teknologi, sehingga minat baca memainkan peran sebagai modal besar bagi setiap orang dalam mencapai kesuksesan pendidikan, meskipun memiliki karir dalam berbagai bidang. Terdapat beberapa tantangan dan kendala dalam meningkatkan pertumbuhan minat baca seperti keterbatasan jumlah buku cetak, minimnya fasilitas perpustakaan dan lebih menariknya program tayangan televisi. Untuk mengatasi masalah tersebut, tentu saja pemerintah harus melaksanakan berbagai kebijakan yang dapat mendorong minat baca siswa di sekolah dan masyarakat.
\end{abstract}

Kata Kunci: minat baca, koleksi buku, perpustakaan

\begin{abstract}
One of big problems of Indonesian education is the lowness of reading interest amid Indonesian students. The interest and reading culture may encourage in expanding science and technology, therefore reading interest plays important roles as strong capital for everyone in pursuing success in education, though they have career in many areas. There are many challenges and constraints in enhancing reading interest growth amid Indonesian students such as limited amount of published books, inadequate library facility and more amusing program of television. To solve the problems, of course the government has to exercise a number of policies which can generate reading interest of students in school and society
\end{abstract}

Keyword: Reading Interest, book collection, library 


\section{PENDAHULUAN}

Berbagai hasil survei yang dilakukan oleh badan-badan internasional menunjukkan bahwa Indonesia selalu menduduki rangking buruk dalam hampir segala bidang dan aspek pembangunan, termasuk dalam soal pendidikan. Dalam masalah politik, Indonesia banyak disorot karena sejak lama dikenal sebagai negara dengan tata birokrasi yang amburadul sehingga menyebabkan tingkat korupsi yang hampir tertinggi di dunia. Dalam bidang ekonomi pemerintah sangat bergantung kepada bantuan dan utang luar negeri untuk membiayai APBN. Berdasarkan hasil laporan terbaru, negara Indonesia juga menduduki rangking terbawah di antara negara-negara lain dalam soal kemudahan investasi.

Tidak jauh berbeda, demikian juga halnya dengan masalah pendidikan. Kondisi pendidikan Indonesia masih jauh dari harapan. Berdasarkan hasil PISA (Program for International Student Assesment) menunjukkan kurang memadainya hasil belajar dalam pendidikan dasar dan menengah di Indonesia. Salah satu contohnya dalam hal keterampilan membaca menunjukkan $70 \%$ siswa Indonesia berada di bawah kompetensi minimum. Dalam kemampuan Matematika menunjukkan $71 \%$ siswa Indonesia berada di bawah kompetensi minimum. Dalam bidang Sains menunjukkan 60\% siswa Indonesia berada di bawah kompetensi minimum (Syahril, 2020).

Data tahun 2018 menunjukkan bahwa peringkat membaca siswa Indonesia mencapai peringkat ke-72 dari 77. Peringkat Matematika adalah 72 dari 78. Dalam bidang Sains, peringkat ke-70 dari 78. Indonesia konsisten sebagai negara dengan peringkat hasil PISA terendah. Skor PISA mengalami stagnan dalam 1015 tahun terakhir. Namun demikian, selisih skor dengan rata-rata skor oleh Organisasi Kerja Sama Ekonomi dan Pembangunan (OECD) sudah sedikit meningkat.

Membaca adalah kegiatan yang seharusnya merupakan kebiasaan dan dilibatkan dalam kegiatan sehari-hari. Indonesia agaknya mengalami masalah dengan aktivitas produktif yang satu ini. Padahal, Bojovic (2014) menyatakan bahwa membaca adalah kegiatan yang harus dibiasakan karena membaca merupakan kegiatan kompleks, yang memiliki tujuan, bersifat interaktif, membutuhkan pemahaman yang termasuk kegiatan fleksibel yang memakan waktu dan sumber penting (dalam Sari, 2018). Hal ini tentunya akan sangat berdampak pada kualitas Sumber Daya Manusia (SDM) di Indonesia itu sendiri.

Kualitas Sumber Daya Manusia (SDM) Indonesia yang diukur dari indikator HDI (Human Development Index) juga menduduki rangking buruk, jauh di bawah beberapa negara tetangga. Dalam sebuah publikasi UNDP, "Human Development Report 2003", Indonesia ditempatkan pada peringkat ke-112 dari 174 negara dalam hal kualitas bangsa. Di dalam daftar ini, Indonesia berada di bawah Vietnam (109), Thailand (74), Malaysia (58) dan Brunei Darussalam (31). Salah satu masalah yang menyebabkan rendahnya kualitas SDM Indonesia karena tingkat melek huruf (literacy rate) penduduknya yang rendah. Angka melek huruf di Indonesia relatif belum tinggi yaitu $88 \%$. Di negara maju seperti Jepang, angkanya sudah mencapai $99 \%$. Sebagian dari penduduk yang tidak memiliki 
kebiasaan membaca secara memadai sangat berpotensi untuk menurunkan angka melek huruf tersebut.

Sebagaimana yang dijelaskan di atas, banyak permasalahan yang dihadapi bangsa Indonesia ini terutama dalam bidang pendidikan. Diantara berbagai persoalan tersebut yang menjadi fokus yang dibahas dalam tulisan ini adalah masih rendahnya minat baca dan kebiasaan membaca bagi sebagian besar masyarakat Indonesia.

Rasanya sesuatu yang mustahil mengharapkan ilmu pengetahuan dan teknologi berkembang sehingga Indonesia memiliki peradaban yang tinggi, tanpa didukung oleh tradisi membaca yang baik di kalangan masyarakat. Budaya membaca merupakan salah satu landasan pokok kemajuan dari dunia pendidikan itu sendiri.

\section{METODOLOGI}

Metodologi yang digunakan dalam penelitian ini adalah survei ke beberapa sekolah dasar, sekolah menengah pertama dan sekolah menengah atas di Padang Panjang. Selain itu, digunakan pula teknik wawancara dengan beberapa guru dan pegiat literasi di Kota Padang Panjang. Untuk mendapatkan data umum dilakukan library research di Perpustakaan dan Arsip Daerah Kota Padang Panjang dengan masa penelitian pada bulan Agustus 2020.

\section{HASIL PENELITIAN DAN PEMBAHASAN}

World Bank dalam salah satu laporan pendidikannya, "Education in Indonesia - From Crisis to Recovery" (1998) melukiskan begitu rendahnya kemampuan membaca anak-anak Indonesia. Dengan mengutip hasil studi dari Vincent Greanary, dilukiskan siswa-siswa kelas enam SD di Indonesia dengan nilai 51,7 berada di urutan paling rendah setelah Filipina $(52,6)$, Thailand $(65,1)$, Singapura $(74,0)$ dan Hongkong $(75,5)$. Artinya, kemampuan membaca siswa Indonesia memang paling buruk dibandingkan siswa dari negara-negara lainnya (Ki Supriyoko, 2004). Sementara itu, pada tahun 2000, organisasi Internasional Education Achievement (IEA) menempatkan kemampuan membaca siswa SD Indonesia di urutan ke-38 dari 39 negara, atau terendah di antara negara-negara ASEAN (Republika, 24 Januari 2003).

Gambaran tersebut tentu saja sangat ironis, apalagi mengingat beberapa kurikulum yang diterapkan untuk murid SD selama ini sudah begitu kompleksnya. Bukan saja jumlah mata pelajaran yang sudah cukup banyak tetapi juga alokasi atau durasi belajar juga terlalu tinggi. Karena itu, bila dibandingkan dengan murid SD pada dasawarsa sebelumnya, murid SD sekarang jauh lebih sibuk dengan kegiatan belajar sehingga hampir tidak ada waktu untuk bermain. Tentu saja ada sesuatu yang salah sesungguhnya dari kurikulum yang begitu bejibun tersebut. Paling tidak dari materi-materi pelajaran yang diberikan ternyata kemudian tidak memberikan stimulus yang memadai bagi membangun budaya baca di kalangan murid. 
Hal yang sama sesungguhnya juga terjadi di kalangan SLTP, SMA dan SMK. Paling tidak, hal ini terlihat dari minimnya sarana perpustakaan yang tersedia di sekolah. Bukan hanya tidak tersedianya ruang baca yang nyaman dan memadai, tetapi juga dari koleksi yang ada hanya memuat buku materi wajib pelajaran, buku paket dan sejumlah buku yang didrop dari pusat (Depdikbud). Sedikit sekali tersedia buku-buku yang bersifat ilmu pengetahuan umum dan bacaan terbaru yang bermutu dan menarik. Kalau dilihat secara umum, masih banyak sekolah yang tidak memiliki perpustakaan sama sekali. Untuk itu diperlukan strategi dan pendekatan-pendekatan dalam rangka meningkatkan kemampuan dan pemahaman membaca yang sesuai dengan tingkat sekolahnya karena setiap level membutuhkan pendekatan atau strategi yang berbeda pula (Ati, 2017).

Membaca adalah sebuah kegiatan keilmuan atau aktivitas intelektual. Dengan membaca manusia menyerap banyak informasi, ilmu pengetahuan untuk memperkaya wawasan yang selanjutnya dapat membantu memecahkan masalah, mengambil keputusan, menentukan kebijakan dan menambah kearifan dalam mempengaruhi kehidupan. Untuk itu, kegiatan membaca bukan hanya harus dilakukan pada saat menempuh pendidikan, melainkan selama hidup.

Dengan memahami kegiatan membaca sebagai proses belajar tersebut, maka dapat dikatakan bahwa membaca merupakan landasan ilmu pengetahuan. Karena pengetahuan, ilmu, teori-teori dan informasi yang berharga akan ditemukan dalam lembaran buku-buku serta berbagai dokumen yang diterbitkan. Intisari pemikiran dari orang-orang hebat, tokoh-tokoh terkenal dan teori-teori yang mengubah dunia ditulis dalam bentuk buku. Sebuah pemikiran atau teori yang dikemukakan oleh seseorang kemudian dibaca, setelah itu dipelajari dan didiskusikan, yang pada akhirnya akan melahirkan pemikiran baru yang bisa saja membantah atau menyempurnakan teori yang sudah ada. Kalau teori pertama disebut sebagai sebuah tesis, maka pemikiran atau teori baru yang menentangnya disebut antitesis. Kedua pemikiran tersebut melahirkan sintesis. Secara sederhana, hubungan antara pemikiran dengan pertumbuhan ilmu pengetahuan terus berkembang dan berubah.

Kegiatan membaca tentu saja sangat erat hubungannya dengan kegiatan menulis. Dapat dikatakan bahwa membaca merupakan modal untuk bisa mengarang atau menulis. Adalah mustahil seseorang dapat menulis atau mengarang dengan baik, tanpa membaca. Menurut Atmazaki (2006), peradaban bangsa ditentukan oleh seberapa banyak pengarang dari bangsa itu menghasilkan buku untuk dibaca masyarakatnya.

"mengarang memang penting karena mengarang merupakan prestasi puncak berkomunikasi. Tinggi rendahnya peradaban suatu bangsa ditentukan oleh banyaknya karangan pada bangsa itu. Ilmu pengetahuan dan teknologi serta kebudayaan disebarluaskan dan diwariskan melalui tulisan atau karangan" (Atmazaki, 2006: v).

Melalui buku, ilmu pengetahuan yang diperoleh dapat diwariskan ke generasi berikutnya dan digunakan sebagai jembatan perantara dalam meningkatkan terus peradabannya ke tingkat yang lebih tinggi. 
Ada sejumlah permasalahan seputar pengembangan minat baca yang dialami oleh Indonesia, seperti soal penerbitan buku yang terbatas dan kondisi perpustakaan yang menyedihkan. Rendahnya minat baca dan konsumsi buku oleh masyarakat dapat diukur dari jumlah buku yang diterbitkan.

Produksi buku memainkan peranan yang sangat penting dalam menumbuhkan minat baca. Buku merupakan media perantara yang menjembatani pikiran pengarang dengan pembacanya. Melalui buku pula pemikiran pengarang lintas generasi dapat saling bertemu.

Buku bagaikan dunia yang dijilid. Seluruh hasil cipta, karsa dan karya manusia dapat dilestarikan. Di dalam buku tersimpan rekamanrekaman teori yang dapat melahirkan suatu teori baru. Bukankah setiap penemuan suatu teori baru selalu dilandasi oleh teori sebelumnya? Sebagaimana yang dikatakan oleh Isac Newton: "Jika saya mampu melihat jauh, hal itu disebabkan karena saya berdiri di pundak para jenius terdahulu" (Kartika and Nugrahanto, 2014).

Berdasarkan data dari International Publisher Association, produksi perbukuan paling tinggi ditunjukkan oleh Inggris, yaitu mencapai rata-rata 100.000 judul buku per tahun. Tahun 2000 saja sebanyak 110.155 judul buku. Posisi kedua ditempati oleh Jerman dengan jumlah judul buku yang diterbitkan tahun 2000 mencapai 80.779 judul. Jepang sebanyak 65.430 judul buku. Sementara itu, Amerika Serikat menempati urutan ke-empat. Indonesia pada tahun 1997 pernah menghasilkan 5.000-an judul buku, tetapi pada tahun 2002 tercatat hanya sekitar 2.700-an judul (Republika Online, 24 Januari 2003).

Melihat angka-angka terbitan buku yang demikian rendah, tentu saja tidak sepadan dengan jumlah penduduk Indonesia yang mencapai 220 juta. Ini juga berhubungan dengan kondisi keilmuan dan intelektual bangsa Indonesia yang jauh tertinggal dibandingkan dengan negara-negara maju. Sebabnya bukan hanya masalah rendahnya produktivitas hasil karya dari kalangan yang berprofesi sebagai guru, dosen, ilmuwan dan peneliti, akan tetapi juga didukung oleh kurangnya penghargaan terhadap karya ilmuwan dan peneliti itu sendiri.

Dari beberapa kasus, sesungguhnya ada keinginan dari pengarang, penulis dan peneliti untuk menerbitkan karyanya untuk dijadikan buku, akan tetapi imbalan dan penghargaan yang diterima dari lembaga penerbit itu sangat rendah, sehingga menjadikan minat tersebut pupus. Di sinilah peran pemerintah dalam regulasi dan pengawasan terhadap usaha penerbitan dan hak cipta terasa longgar, menyebabkan banyak sekali praktek curang yang dilakukan penerbit yang menyebabkan pengarang menjadi korban. Misalnya kasus pelanggaran hak cipta dan royalti, pembajakan buku dan kurangnya imbalan yang pantas untuk penulis buku.

Persoalan lain yang menyebabkan rendahnya minat baca adalah karena mahalnya harga buku sehingga tidak terjangkau oleh masyarakat secara umum. Sudah banyak keluhan yang dilontarkan oleh para orang tua akan tingginya harga buku yang diwajibkan untuk dimiliki oleh pihak sekolah. Persoalan yang sama 
juga dialami oleh para mahasiswa dimana harga buku tidak terjangkau oleh kantong, sementara buku-buku tersebut jarang ditemukan di perpustakaan.

Kalau pemerintah memang serius untuk memajukan dunia pendidikan, tentu saja dalam pengadaan buku-buku untuk sekolah dan perguruan tinggi seharusnya mempertimbangkan kebijakan subsidi. Pemerintah hendaknya memiliki kebijakan untuk merangsang dan menghargai para pengarang dan penulis dalam menerbitkan karya-karya bermutunya.

Masalah berikutnya adalah keberadaan perpustakaan yang terabaikan dalam dunia pendidikan Indonesia. Di negara yang sudah maju, perpustakaan merupakan cermin kemajuan masyarakatnya karena itu menunjukkan perpustakaan adalah bagian dari kebutuhan hidup sehari-hari. Hal itu diikuti dengan kemudahan memperoleh akses dan kelengkapan sarana dan ketersediaan sumber informasi yang sangat memadai (Sutarno, 2005:3).

Sementara di negara-negara berkembang khususnya Indonesia, keberadaan, eksistensi dan perhatian masyarakat terhadap perpustakaan masih sangat terbatas. Perpustakaan masih merupakan keinginan (wants) daripada kebutuhan (needs) bagi sementara orang.

Menurut data dari Deputi Pengembangan Perpustakaan Nasional RI (PNRI) dari sekitar 300.000 SD hingga SLTA, baru 5\% saja yang memiliki perpustakaan. Bahkan diduga hanya $1 \%$ dari 260.000 SD yang mempunyai perpustakaan. Juga baru sekitar $20 \%$ dari 66.000 desa/kelurahan yang memiliki perpustakaan yang memadai (Kompas, 25/07/02).

Kondisi perpustakaan di perguruan tinggi juga tidak jauh dari keadaan yang menggembirakan. Kita akui saat ini pertumbuhan jumlah perguruan tinggi baik negeri maupun swasta dari tahun ke tahun berkembang dengan sangat pesat. Akan tetapi sedikit saja dari perguruan tinggi tersebut yang memiliki perpustakaan yang layak dan bagus. Padahal untuk bidang pendidikan tinggi, perpustakaan itu ibarat jantungnya universitas. Kalau tidak ada perpustakaan atau memang tidak berfungsi dengan baik, sama saja artinya perguruan tinggi tersebut "mati suri".

Gambaran di atas tentu saja sangat menyedihkan. Bagaimana mungkin diharapkan anak didik dapat memperoleh pemahaman terhadap materi yang diajarkan secara baik kalau tidak ada fasilitas perpustakaan yang menyediakan buku-buku yang dibutuhkan.

Menumbuhkan minat baca bagi anak-anak dipengaruhi oleh lingkungan terdekat anak yaitu keluarga, sekolah dan lingkungan masyarakat sendiri dimana anak tinggal. Mengenalkan minat baca sudah harus dimulai sejak dini, yaitu oleh anggota keluarga terutama dalam hal ini yang paling bertanggung jawab adalah orang tua. Bila orang tuanya memiliki kebiasaan membaca seperti membaca koran dan mempunyai beberapa koleksi buku, tentu saja ini akan mendorong anak untuk ingin tahu dan meniru apa yang dilihatnya. Untuk itu, secara sadar orang tua harus ikut berperan dengan menyediakan bacaan yang menarik sesuai dengan umur dan perkembangan anak. 
Akan tetapi dari banyak kasus anak-anak justru menggunakan waktu luangnya dengan menonton televisi yang justru menyediakan banyak acara yang menarik bagi anak-anak seperti film, telenovela atau tayangan berbau iklan. Anakanak sering dibiarkan tanpa kontrol menonton televisi. Hal ini bukan hanya membunuh minat baca anak, tetapi sekaligus merusak kepribadian anak. Tayangan televisi banyak menyajikan hal-hal yang berbau pornografi dan kekerasan. Kondisi ini diperparah ketika kedua orang tua sibuk bekerja sehingga kebiasaan buruk anak dalam menonton nyaris tidak lagi terkontrol.

Dengan demikian dapat dikatakan bahwa upaya menumbuhkan minat baca juga akan lebih mudah dan efektif apabila dilakukan sejak dini, sejak kanakkanak. Ini artinya orang tua sangat dituntut keikutsertaannya. Orang tua harus memastikan bahwa kecintaan akan membaca adalah tujuan pendidikan yang terpenting bagi anak-anaknya kelak. Tradisi dan kebiasaan membaca merupakan modal utama bagi anak untuk menggeluti bidang pekerjaan apapun nantinya.

Untuk merangsang anak-anak agar tumbuh minat baca, diperlukan bukubuku yang bersifat menghibur sekaligus mendidik. Selain itu, buku dimaksud harus menarik dengan dilengkapi gambar atau ilustrasi yang bagus termasuk kulit depannya. Tidak sampai di situ saja, sesuai dengan tahap psikologisnya, anakanak lebih menyukai buku cerita. Karya sastra seperti novel, cerpen dan jenis prosa lainnya merupakan salah satu media yang tepat untuk membangkitkan minat baca. Sebab, produk-produk sastra itu menyajikan cerita. Berbeda halnya dengan buku paket atau buku-buku pelajaran lainnya. Cerita dalam karya sastra mengisahkan tokoh-tokoh dalam dunia fiksi yang tidak lepas begitu saja dengan dunia nyata. Karya sastra tersebut mengandung pesan moral, mengembangkan imajinasi dan menawarkan pengalaman baru bagi pembacanya.

Seorang peneliti sastra, Riris K. Toha Sarumpaet pernah mengatakan bahwa sastra adalah satu dunia yang menawarkan keutuhan yang dapat menggerakkan jiwa dan rasa yang dapat mengubah manusia menjadi lebih halus dan peka. Setiap kata dalam sastra itu menawarkan satu moral. Moral itu terjalin menjadi jiwa cerita, menjadi nafas, ucapan dan perilaku para tokohnya. Itulah sebabnya, buku yang bernilai sastra selalu dapat memberikan ajaran yang baik yang dapat memperkaya batin manusia (Bali Post, 12 Desember 2004).

\section{KESIMPULAN DAN SARAN}

Rendahnya minat baca dan kebiasaan membaca masyarakat Indonesia merupakan salah satu persoalan pokok dunia pendidikan, bahkan masalah ini diduga berhubungan dengan berbagai kemunduran kualitas dan mutu pendidikan Indonesia sejak beberapa tahun terakhir. Banyak faktor yang menyebabkan rendahnya minat baca para siswa sekolah dan masyarakat secara umum, seperti harga buku yang tidak terjangkau, kurangnya fasilitas perpustakaan, tidak adanya perhatian dan kesadaran dari keluarga dan lingkungan untuk menumbuhkan minat baca anak sejak dini, dan juga belum maksimalnya keseriusan pemerintah untuk memajukan minat baca masyarakat. Semua faktor-faktor tersebut tentu saja tidak berdiri sendiri, malah satu sama lain berhubungan dan saling mempengaruhi. Untuk itu, sudah saatnya sekarang pemerintah mengeluarkan berbagai kebijakan yang dapat menciptakan iklim yang kondusif untuk tumbuhnya minat baca dan 
berkembangnya tradisi membaca bagi para siswa, mahasiswa dan kalangan masyarakat secara umum. Dengan demikian diharapkan berbagai persoalan tentang kemunduran dunia pendidikan Indonesia makin lama semakin teratasi untuk selanjutnya mengalami kemajuan sebagaimana yang sudah terjadi pada negara-negara tetangga.

\section{DAFTAR PUSTAKA}

Ati, Harni. 2017. "Peningkatan Kemampuan Membaca Pemahaman dengan Menggunakan Pendekatan Construktivisme di Kelas IV SDN Api-api Kecamatan Bayang" dalam Jurnal Inovasi Pendidikan Vol. 2 (8)

Atmazaki. 2006. Kiat-kiat Mengarang dan Menyunting. Padang: Yayasan Citra Budaya Indonesia

Kartika and Nugrahanto.2014. Mengembangkan Minat Baca di Masyarakat Desa Pasanggrahan Dan Desa Malongpong Kecamatan Maja Kabupaten Majalengka. Dalam "Dharmakarya: Jurnal Aplikasi Ipteks Untuk Masyarakat", ISSN 1410-5675.

Sari, Mezia Kemala dan Lisa Rana Sari. 2018. "The Effect of Anticipation Guide Strategy on Student's Reading Comprehension" dalam Jurnal Ta'dib 22 (1); $51-56$

Sutarno, NS. 2005. Tanggung Jawab Perpustakaan Dalam Mengembangkan Masyarakat Informasi”. Jakarta: Panta Rei.

Syahril, Iwan. Ph.D dalam presentasi webinar internasional "Profesionalisme Guru di Kota Padang Panjang Menjawab Tantangan Zaman Khususnya Era Revolusi Industri 4.0" yang diselenggarakan UMSB tanggal 31 Agustus 2020.

$\mathrm{Ki}$ Supriyoko. "Minat Baca dan Kualitas Bangsa". http://www.pikiranrakyat.com/cetak/0304/23/0801.htm. Diakses tanggal 20 Juli 2020.

S. Nasution.1998. Buku Penuntun Membuat Thesis, Skripsi, Disertasi, Makalah. Bandung: Penerbit Jemmars.

"Butuh Peran Guru untuk Tumbuhkan Minat Baca". http://www.kompas.com/kompas-cetak/0405/17/Jabar/1028887.htm.

Diakses tanggal 20 Juli 2020.

"Perpustakaan, Buku dan Minat Baca". Republika onlinehttp://www.republika.co.id. Diakses tanggal 19 Juli 2020.

"Sumbangan Sastra Terhadap Minat http://balipost.co.id/BaliPostcetak/2003/12/15/fe1.htm. Diakses tanggal 20 Juli 2020. 